\title{
Effects of yeast combined with chromium propionate on growth performance and carcass quality of finishing steers 1
}

\author{
C. L. Van Bibber-Krueger,* J. E. Axman,* J. M. Gonzalez,* C. I. Vahl, $\dagger$ and J. S. Drouillard*2 \\ * Department of Animal Sciences and Industry, Kansas State University, \\ Manhattan 66506; and †Department of Statistics, Kansas State University, Manhattan 66506
}

\begin{abstract}
A combination of yeast and chromium propionate $(\mathrm{Y}+\mathrm{Cr})$ was added to the diets of crossbred finishing steers $(n=504 ; 402 \mathrm{~kg} \pm 5.76$ initial BW) to evaluate impact on feedlot performance and carcass traits. We hypothesized supplementation of $\mathrm{Y}+\mathrm{Cr}$ would increase growth of feedlot steers. Steers with initial plasma glucose concentrations $\leq 6.0 \mathrm{~m} M$ were stratified by initial BW and randomly allocated, within strata, to receive 0 (control) or $3.3 \mathrm{~g} / \mathrm{d} \mathrm{Y}+\mathrm{Cr}$. Steers were further divided into heavy and light weight blocks with 6 pens/diet within each weight block. Cattle were housed in dirt-surfaced pens with 21 steers/pen and had ad libitum access to feed. Body weights were measured at 21-d intervals. Blood samples were collected on d 49 and 94 from a subset of steers (5/pen) for analyses of plasma glucose and lactate concentrations. At the end of the finishing phase, animals were weighed and transported $450 \mathrm{~km}$ to an abattoir in Holcomb, KS. Severity of liver abscesses and HCW were collected the day of harvest, and after $36 \mathrm{~h}$ of refrigeration, USDA yield and quality grades, LM area, and 12th rib subcutaneous fat thickness were determined. There were no treatment $\times$ time $\times$ weight block interactions $(P>0.05)$ and no
\end{abstract}

treatment $\times$ block interaction for ADG, DMI, or final BW $(P \geq 0.06)$, but a treatment $\times$ block interaction $(P=$ 0.03 ) was observed for G:F, in which control, light cattle had poorer efficiency compared with other groups. Treatment $\times$ weight group interactions were observed for overall yield grade and carcasses that graded yield grade $1(P \leq 0.04)$. Light steers supplemented with $\mathrm{Y}+\mathrm{Cr}$ had decreased overall yield grade and increased percentage of carcasses grading yield grade 1 compared with their control counterparts, with no differences observed for heavy steers. Regardless of weight group, a greater percentage of carcasses from steers supplemented with $\mathrm{Y}+\mathrm{Cr}$ graded yield grade $2(P=0.03)$ and fewer carcasses from steers supplemented $\mathrm{Y}+\mathrm{Cr}$ graded yield grade $3(P<0.01)$ than control steers. No interactions or effects of treatment were detected for other carcass measurements $(P \geq 0.07)$. There were no treatment $\times$ weight group interactions or effects of treatment for plasma glucose or lactate concentrations on d 49 or $94(P>0.10)$. Overall, yeast in combination with chromium propionate may improve feed efficiency and decrease yield grade of light cattle but had no effect on remaining carcass traits and blood constituents.

Key words: beef cattle, carcass traits, chromium propionate, glucose, yeast

(C) 2016 American Society of Animal Science. All rights reserved. J. Anim. Sci. 2016.94:3003-3011 doi:10.2527/jas2016-0454

\section{INTRODUCTION}

Chromium is an essential micromineral that functions as a component of glucose tolerance factor and chromodulin, both of which potentiate actions of insulin (NRC, 2000; Pechova and Pavlata, 2007). Chromium

\footnotetext{
${ }^{1}$ This is contribution number $16-258-\mathrm{J}$ from the Kansas Agricultural Experiment Station.

${ }^{2}$ Corresponding author: jdrouill@ksu.edu

Received March 10, 2016.

Accepted May 4, 2016.
}

has been implicated as a regulator of lipid and protein metabolism (Pechova and Pavlata, 2007). Enhanced lipogenesis and decreased lipolysis were observed in dairy cattle supplemented chromium propionate (McNamara and Valdez, 2005), which suggests chromium propionate might influence quality and yield grades in finishing cattle. In addition, Cr supplementation has the potential to increase AA uptake by muscle cells, potentially increasing total protein deposition (Pechova and Pavlata, 2007). The ability of Cr to increase glucose tolerance through effects on insulin function could improve efficiency of glucose utilization, thus leading to 
improved growth and efficiency (Swanson et al., 2000); however, little is known about actual requirements of $\mathrm{Cr}$ for finishing cattle. Some studies revealed favorable performance responses to $\mathrm{Cr}$ during periods of stress in ruminants. Stressed feeder calves were administered a high-Cr yeast product, which improved ADG (Chang and Mowat, 1992; Moonsie-Shageer and Mowat, 1993), feed efficiency (Chang and Mowat, 1992), and immune response (Moonsie-Shageer and Mowat, 1993).

Organic forms of $\mathrm{Cr}$ are readily absorbed, are more physiologically active, and require no dietary precursors (i.e., AA or niacin) for bioactivity (Mowat, 1997) compared with inorganic sources. Chromium propionate is currently the only form of supplemented $\mathrm{Cr}$ approved for addition to cattle diets in the United States. We hypothesized that chromium propionate, when supplemented in combination with yeast culture, would increase gain and feed efficiency during the finishing phase. The objectives of this study were to compare feedlot performance, carcass characteristics, and plasma glucose profiles of cattle fed finishing diets with and without a combination of yeast and chromium propionate.

\section{MATERIALS AND METHODS}

Protocols and procedures followed in this study were approved by the Kansas State University Institutional Animal Care and Use Committee. The study was conducted at the Kansas State University Beef Cattle Research Center located in Manhattan, KS. The trial started October 2013 and finished February 2014.

\section{Experimental Design}

The study was conducted as a randomized complete block design with 2 treatments using 504 crossbred steers $(402 \mathrm{~kg} \pm 5.76 \mathrm{BW})$. Steers were from a larger population of crossbreed cattle and were selected on the basis of initial plasma glucose concentrations; steers with plasma glucose concentrations greater than $6.0 \mathrm{mM}$ were excluded. Steers were then blocked by initial BW (12 blocks) and randomly allocated within block to 2 treatments. Animals were further divided into heavy (421 kg \pm 5.76 gross BW) and light ( $384 \mathrm{~kg} \pm 5.76$ gross $\mathrm{BW})$ weight groups to determine if treatment differences existed between heavy and light animals. Steers were housed in 24 pens containing 21 steers/pen (12 pens/ treatment). Treatments consisted of a control, in which the steers received a basal diet (control), and a treatment that contained the basal diet with a combination of yeast (Saccharomyces cerevisiae) and chromium propionate $(\mathbf{Y}+\mathbf{C r}$; Vi-COR, Mason City, IA) added to the feed additive premix. Each treatment was represented in each weight group (i.e., control light, $\mathrm{Y}+\mathrm{Cr}$ light, control
Table 1. Composition of finishing diet fed to steers supplemented with and without yeast combined with chromium propionate

\begin{tabular}{lc}
\hline \hline Item & Percent DM \\
\hline Ingredient & \\
Steam-flaked corn & 57.90 \\
Wet corn gluten feed & 30.00 \\
Ground alfalfa & 8.00 \\
Limestone & 1.46 \\
Salt & 0.30 \\
Vitamin/mineral premix ${ }^{1}$ & 0.18 \\
Feed additive premix ${ }^{2}$ & 2.16 \\
Calculated nutrient composition ${ }^{3}$ & \\
CP & 14.1 \\
NDF & 19.4 \\
Ca & 0.70 \\
P & 0.48 \\
$\mathrm{~K}$ & 0.70 \\
\hline
\end{tabular}

${ }^{1}$ Formulated to provide the following added nutrient levels: $2,200 \mathrm{IU} / \mathrm{kg}$ vitamin A, $22 \mathrm{IU} / \mathrm{kg}$ vitamin E (alpha tocopherol acetate), $0.10 \mathrm{mg} / \mathrm{kg}$ Co (cobalt carbonate), $10 \mathrm{mg} / \mathrm{kg} \mathrm{Cu}$ (copper sulfate), $0.6 \mathrm{mg} / \mathrm{kg} \mathrm{I} \mathrm{(ethylene-}$ diamine dihydriodide), $60 \mathrm{mg} / \mathrm{kg} \mathrm{Mn}$ (manganese sulfate), $0.30 \mathrm{mg} / \mathrm{kg} \mathrm{Se}$ (sodium selenite), and $60 \mathrm{mg} / \mathrm{kg} \mathrm{Zn} \mathrm{(zinc} \mathrm{sulfate).}$

${ }^{2}$ Formulated to provide $300 \mathrm{mg} / \mathrm{d}$ monensin and $90 \mathrm{mg} / \mathrm{d}$ tylosin (Elanco Animal Health, Greenfield, IN) in a ground corn carrier. A combination of yeast and chromium propionate ( $\mathrm{Y}+\mathrm{Cr}$; Vi-COR, Mason City, IA) was added to the premix to equal a feeding rate of $3.3 \mathrm{~g} / \mathrm{d}$ (as fed) $\mathrm{Y}+\mathrm{Cr}$ treatment to provide $3.2 \mathrm{mg}$ Cr per animal daily.

${ }^{3}$ Nutrient composition was calculated based on NRC (2000) values for individual ingredients.

heavy, and $\mathrm{Y}+\mathrm{Cr}$ heavy). The $\mathrm{Y}+\mathrm{Cr}$ supplement was fed at a rate of $3.3 \mathrm{~g} / \mathrm{d}$ (as fed), which provided $3.2 \mathrm{mg}$ Cr per animal daily (Table 1).

\section{Animal Processing, Housing, and Handling}

Upon arrival at the Kansas State University Beef Cattle Research Center, steers were allowed ad libitum access to ground alfalfa hay and water. Twenty-four hours after arrival of the final load of cattle, steers were tagged with an ear tag that displayed a unique number for each study animal. Before initiation of the study, steers were individually weighed and received an estradiol/trenbolone acetate implant (Component TE-200 with Tylan; Ivy Animal Health, Inc., Overland Park, KS), topical parasiticide (Dectomax; Pfizer Animal Health, New York, NY), 5-way viral vaccine (Bovishield Gold5; Pfizer Animal Health), and 7-way clostridial vaccine (Ultra-Bac 7; Pfizer Animal Health). In addition, blood samples were obtained by jugular venipuncture for analysis of plasma glucose and lactate using $10-\mathrm{mL}$ blood collection tubes containing sodium fluoride/potassium oxalate as anticoagulants (BD Vacutainer; Becton, Dickinson and Company, Franklin Lakes, NJ). Samples were immediately placed on ice and centrifuged within 20 min of sampling. Blood was centrifuged at 2,494 $\times g$ 
Table 2. Growth performance of steers separated into light and heavy weight groups and supplemented 0 (control) or $3.3 \mathrm{~g} / \mathrm{d}$ of a combination of yeast and chromium propionate (Y+Cr; Vi-COR, Mason City, IA) $)^{1,2}$

\begin{tabular}{|c|c|c|c|c|c|c|c|c|}
\hline \multirow[b]{2}{*}{ Item } & \multicolumn{2}{|c|}{ Light } & \multicolumn{2}{|c|}{ Heavy } & \multirow[b]{2}{*}{ SEM } & \multicolumn{3}{|c|}{$P$-value ${ }^{3}$} \\
\hline & Control & $\mathrm{Y}+\mathrm{Cr}$ & Control & $\mathrm{Y}+\mathrm{Cr}$ & & Trt & WG & Trt $\times W G$ \\
\hline Initial no. of steers & 126 & 126 & 126 & 126 & - & - & - & - \\
\hline \multicolumn{9}{|l|}{$\mathrm{BW},{ }^{4} \mathrm{~kg}$} \\
\hline Initial & 384 & 383 & 420 & 420 & 5.76 & 0.91 & $<0.001$ & 0.83 \\
\hline $21 \mathrm{~d}$ & 459 & 463 & 491 & 492 & 4.61 & 0.18 & $<0.01$ & 0.34 \\
\hline $42 \mathrm{~d}$ & 505 & 507 & 535 & 538 & 5.50 & 0.51 & $<0.01$ & 1.00 \\
\hline $63 \mathrm{~d}$ & 551 & 555 & 579 & 584 & 5.05 & 0.27 & $<0.01$ & 0.87 \\
\hline $84 \mathrm{~d}$ & 585 & 590 & 611 & 616 & 4.93 & 0.19 & $<0.01$ & 0.93 \\
\hline $105 \mathrm{~d}$ & 616 & 619 & 646 & 646 & 5.63 & 0.74 & $<0.01$ & 0.75 \\
\hline $126 \mathrm{~d}$ & 634 & 635 & 671 & 669 & 6.08 & 0.86 & $<0.01$ & 0.73 \\
\hline $148 \mathrm{~d}$ & 655 & 663 & - & - & 6.55 & 0.30 & - & - \\
\hline \multicolumn{9}{|l|}{ Day $1-21$} \\
\hline No. of steers & 126 & 126 & 125 & 126 & - & - & - & - \\
\hline $\mathrm{ADG}, \mathrm{kg} / \mathrm{d}$ & $2.59^{\mathrm{a}}$ & $2.87^{\mathrm{b}}$ & $2.58^{\mathrm{a}}$ & $2.49^{\mathrm{a}}$ & 0.09 & 0.21 & 0.08 & 0.02 \\
\hline DMI, kg/d & 12.54 & 12.44 & 12.97 & 12.73 & 0.16 & 0.31 & 0.05 & 0.68 \\
\hline $\mathrm{G}: \mathrm{F}$ & $0.2073^{\mathrm{a}}$ & $0.2314^{\mathrm{b}}$ & $0.1991^{\mathrm{a}}$ & $0.1960^{\mathrm{a}}$ & 0.008 & 0.12 & 0.03 & 0.05 \\
\hline \multicolumn{9}{|l|}{ Day $22-42$} \\
\hline No. of steers & 126 & 126 & 125 & 126 & - & - & - & - \\
\hline $\mathrm{ADG}, \mathrm{kg} / \mathrm{d}$ & 2.20 & 2.10 & 2.12 & 2.19 & 0.09 & 0.86 & 0.92 & 0.37 \\
\hline DMI, kg/d & 12.70 & 12.32 & 13.03 & 12.92 & 0.19 & 0.07 & 0.08 & 0.28 \\
\hline $\mathrm{G}: \mathrm{F}$ & 0.1729 & 0.1703 & 0.1627 & 0.1698 & 0.006 & 0.72 & 0.40 & 0.44 \\
\hline \multicolumn{9}{|l|}{ Day 43-63 } \\
\hline No. of steers & 126 & 126 & 125 & 126 & - & - & - & - \\
\hline $\mathrm{ADG}, \mathrm{kg} / \mathrm{d}$ & 2.20 & 2.25 & 2.11 & 2.21 & 0.07 & 0.19 & 0.45 & 0.63 \\
\hline DMI, kg/d & 12.66 & 12.38 & 13.08 & 13.02 & 0.20 & 0.40 & 0.03 & 0.52 \\
\hline $\mathrm{G}: \mathrm{F}$ & 0.1738 & 0.1820 & 0.1616 & 0.1702 & 0.006 & 0.04 & 0.13 & 0.97 \\
\hline \multicolumn{9}{|l|}{ Day 64-84 } \\
\hline No. of steers & 126 & 126 & 124 & 126 & - & - & - & - \\
\hline $\mathrm{ADG}, \mathrm{kg} / \mathrm{d}$ & 1.59 & 1.68 & 1.50 & 1.51 & 0.07 & 0.33 & 0.18 & 0.38 \\
\hline DMI, kg/d & 13.13 & 12.83 & 13.36 & 13.29 & 0.22 & 0.39 & 0.17 & 0.60 \\
\hline G:F & 0.1209 & 0.1308 & 0.1125 & 0.1134 & 0.005 & 0.09 & 0.07 & 0.16 \\
\hline \multicolumn{9}{|l|}{ Day 85-105 } \\
\hline No. of steers & 126 & 126 & 124 & 126 & - & - & - & - \\
\hline $\mathrm{ADG}, \mathrm{kg} / \mathrm{d}$ & 1.49 & 1.38 & 1.66 & 1.46 & 0.06 & 0.04 & 0.07 & 0.44 \\
\hline DMI, kg/d & 13.10 & 12.47 & 13.26 & 12.93 & 0.25 & 0.09 & 0.25 & 0.58 \\
\hline $\mathrm{G}: \mathrm{F}$ & 0.1135 & 0.1110 & 0.1255 & 0.1127 & 0.004 & 0.08 & 0.12 & 0.22 \\
\hline \multicolumn{9}{|l|}{ Day $106-126$} \\
\hline No. of steers & 126 & 126 & 124 & 126 & - & - & - & - \\
\hline $\mathrm{ADG}, \mathrm{kg} / \mathrm{d}$ & 0.85 & 0.74 & 1.26 & 1.12 & 0.11 & 0.30 & $<0.01$ & 0.92 \\
\hline DMI, kg/d & 11.94 & 11.78 & 12.53 & 12.09 & 0.24 & 0.24 & 0.10 & 0.58 \\
\hline G:F & 0.0715 & 0.0617 & 0.1000 & 0.0933 & 0.009 & 0.38 & $<0.01$ & 0.86 \\
\hline \multicolumn{9}{|l|}{ Day $127-148$} \\
\hline No. of steers & 126 & 125 & - & - & - & - & - & - \\
\hline $\mathrm{ADG}, \mathrm{kg} / \mathrm{d}$ & 0.98 & 1.30 & - & - & 0.12 & 0.07 & - & - \\
\hline DMI, kg/d & 12.16 & 12.02 & - & - & 0.24 & 0.68 & - & - \\
\hline G:F & 0.0811 & 0.1087 & - & - & 0.01 & 0.11 & - & - \\
\hline \multicolumn{9}{|l|}{ Overall $^{5}$} \\
\hline $\mathrm{ADG}, \mathrm{kg} / \mathrm{d}$ & 1.70 & 1.76 & 1.88 & 1.84 & 0.03 & 0.69 & $<0.001$ & 0.06 \\
\hline DMI, $\mathrm{kg} / \mathrm{d}$ & 12.57 & 12.29 & 13.00 & 12.83 & 0.17 & 0.18 & 0.03 & 0.75 \\
\hline $\mathrm{G}: \mathrm{F}$ & $0.1349^{\mathrm{a}}$ & $0.1430^{\mathrm{b}}$ & $0.1445^{\mathrm{b}}$ & $0.1434^{b}$ & 0.002 & 0.08 & 0.09 & 0.03 \\
\hline
\end{tabular}

a,b Within a row, means without a common superscript letter are different $(P \leq 0.05)$.

${ }^{1}$ Provided $3.2 \mathrm{mg} \mathrm{Cr} / \mathrm{d}$.

${ }^{2}$ Heavy block shipped Day 125 and light block shipped Day 148.

${ }^{3} \mathrm{Trt}=$ effect of treatment; $\mathrm{WG}=$ effect of weight group.

${ }^{4} \mathrm{BW}$ measurements $=$ gross $\mathrm{BW}$.

${ }^{5}$ From trial initiation through harvest. 
Table 3. Carcass traits of steers separated into light and heavy weight groups and supplemented 0 (control) or $3.3 \mathrm{~g} / \mathrm{d}$ of a combination of yeast and chromium propionate $\left(\mathrm{Y}+\mathrm{Cr}\right.$; Vi-COR, Mason City, IA) ${ }^{1}$

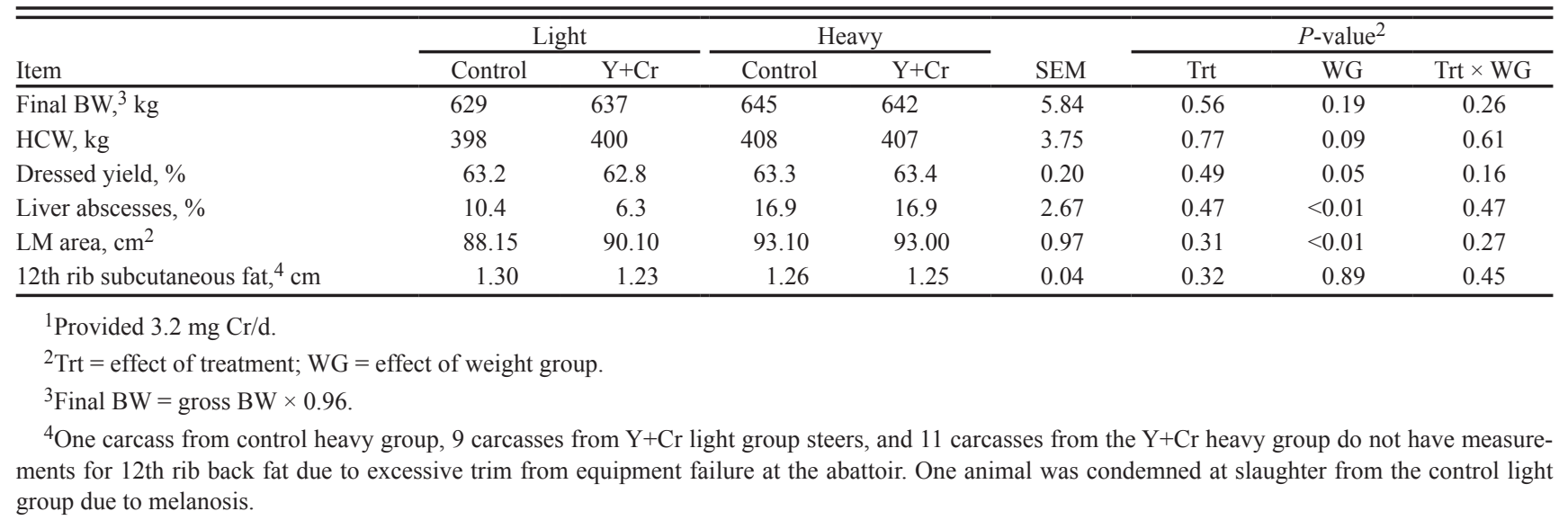

for $20 \mathrm{~min}$ at room temperature, and plasma was transferred by pipette into $5-\mathrm{mL}$ plastic tubes and frozen at $-20^{\circ} \mathrm{C}$ for subsequent analysis. Steers were housed in dirt-surfaced pens that were 10.1 by $30.5 \mathrm{~m}$ and of pipe construction. Watering fountains were shared between adjacent feedlot pens and steers were allowed ad libitum access to feed and water. Body weights (gross BW) were captured for each pen at 21-d intervals (single day measurements) and again at the end of feedlot finishing. Average daily gains were computed by subtracting previous $\mathrm{BW}$ from current $\mathrm{BW}$ for each weigh period and divided by days on feed (DOF). Gain efficiencies were computed as ADG divided by DMI.

Blood was drawn by jugular venipuncture from 5 steers/pen approximately $2 \mathrm{~h}$ prior to feeding on $\mathrm{d} 49$ and 94 to determine plasma glucose and lactate concentrations. Blood collection for each pen lasted approximately $10 \mathrm{~min}$. Steers used for blood collection were randomly chosen at the beginning of the study and tagged with a colored ear tag for identification. Blood sampling procedures were as previously described, and samples were stored at $-20^{\circ} \mathrm{C}$ until analysis. Glucose and lactate concentrations of plasma were analyzed using the YSI 2300 STAT Plus Glucose and L-Lactate Analyzer (YSI Inc., Yellow Springs, OH).

\section{Diet Preparation}

Steers were transitioned to finishing diets over a period of $18 \mathrm{~d}$ using a series of 3 step-up diets (roughage:concentrate ratios of 46:54, 33:67, and 21:79; $6 \mathrm{~d} /$ step) that were formulated to allow gradual adaptation to the high-grain finishing diet. A mixture of yeast and chromium propionate $(3.3 \mathrm{~g} / \mathrm{d})$ was added to the feed additive premix, which subsequently was mixed into total mixed rations for all step-up and final diets of steers supplemented $\mathrm{Y}+\mathrm{Cr}$ only. Yeast combined with chromium propionate was replaced with ground corn in the feed additive premix for control steers. Diets were mixed once daily in a truck-mounted mixer and delivered to cattle at approximately $0800 \mathrm{~h}$. Feed intakes were visually monitored and adjusted daily so only trace amounts of residual feed remained the following day. Unconsumed feed was removed from the bunk and weighed at 21-d intervals or as needed to determine actual feed intake for each 21-d period. Subsamples of diets and unconsumed feed were dried at $55^{\circ} \mathrm{C}$ for 48 $\mathrm{h}$ to determine DM content. For each 21-d interval and for the total study period, DMI was computed as DMI = [(total feed offered $\times \%$ DM $)-($ total feed refused $\times \%$ $\mathrm{DM})] /($ number of animals $\times$ day).

\section{Harvest}

Final BW were determined immediately before cattle were shipped on the day of harvest. Final BW was multiplied by 0.96 to account for $4 \%$ shrink during shipping. Steers were loaded onto a truck and transported $451 \mathrm{~km}$ to a commercial abattoir in Holcomb, KS. Steers in the heavy block were shipped after 125 DOF and steers in the light block were shipped after 148 DOF. Incidence and severity of liver abscesses and $\mathrm{HCW}$ were recorded the day of harvest. Liver abscesses were scored according to the Elanco scoring system (Liver Abscess Technical Information AI 6288; Elanco Animal Health, Greenfield, IN): $0=$ no abscesses; $\mathrm{A}^{-}=1$ or 2 small abscesses or abscess scars; $\mathrm{A}=2$ to 4 small, well-organized abscesses; and $\mathrm{A}^{+}=1$ or more large or active abscesses with or without adhesions. United States Department of Agriculture yield grade, USDA quality grade, marbling score, 12th rib subcutaneous fat thickness, LM area, and incidence and severity of dark cutting beef were collected after $36 \mathrm{~h}$ of refrigeration from camera images (VBG 2000; E+V Technology GmbH \& Co. KG, Oranienburg, Germany) provided by the abattoir; however, due to equipment failure that occurred at the abattoir, LM area 
Table 4. Quality and yield grades of steers separated into light and heavy weight groups and supplemented 0 (control) or $3.3 \mathrm{~g} / \mathrm{d}$ of a combination of yeast and chromium propionate (Y+Cr; Vi-COR, Mason City, IA) ${ }^{1}$

\begin{tabular}{|c|c|c|c|c|c|c|c|c|}
\hline \multirow[b]{2}{*}{ Item } & \multicolumn{2}{|c|}{ Light } & \multicolumn{2}{|c|}{ Heavy } & \multirow[b]{2}{*}{ SEM } & \multicolumn{3}{|c|}{$P$-value ${ }^{2}$} \\
\hline & Control & $\mathrm{Y}+\mathrm{Cr}$ & Control & $\mathrm{Y}+\mathrm{Cr}$ & & Trt & WG & Trt $\times W G$ \\
\hline$\overline{\text { USDA Prime, } \%}$ & 0.8 & 0.8 & 0.0 & 0.8 & 0.70 & 0.56 & 0.60 & 0.56 \\
\hline USDA high Choice, $\%$ & 6.4 & 5.6 & 5.7 & 0.0 & 1.81 & 0.02 & 0.19 & 0.07 \\
\hline USDA mid Choice, $\%$ & 23.3 & 19.1 & 13.0 & 8.9 & 3.51 & 0.23 & 0.02 & 1.00 \\
\hline USDA low Choice, $\%$ & 44.0 & 44.8 & 42.9 & 44.0 & 5.25 & 0.86 & 0.86 & 0.97 \\
\hline USDA Select, \% & 25.5 & 27.2 & 36.0 & 43.9 & 5.21 & 0.38 & 0.03 & 0.57 \\
\hline USDA Standard, \% & 0.0 & 0.8 & 1.6 & 1.6 & 1.03 & 0.69 & 0.28 & 0.69 \\
\hline B-maturity, $\%$ & 0.0 & 1.7 & 0.8 & 0.8 & 1.02 & 0.43 & 1.00 & 0.43 \\
\hline Overall yield grade & $2.79^{\mathrm{a}}$ & $2.54^{\mathrm{b}}$ & $2.66^{\mathrm{ab}}$ & $2.67^{\mathrm{ab}}$ & 0.05 & 0.02 & 1.00 & 0.02 \\
\hline Yield grade 1, \% & $4.0^{\mathrm{b}}$ & $10.4^{\mathrm{a}}$ & $6.4^{\mathrm{ab}}$ & $5.6^{\mathrm{ab}}$ & 1.51 & 0.09 & 0.45 & 0.04 \\
\hline Yield grade 2, \% & 30.5 & 40.9 & 30.5 & 35.1 & 3.70 & 0.03 & 0.53 & 0.34 \\
\hline Yield grade 3, \% & 49.5 & 35.9 & 55.0 & 48.1 & 4.15 & $<0.01$ & 0.13 & 0.21 \\
\hline Yield grade $4, \%$ & 15.2 & 10.4 & 6.5 & 9.6 & 2.36 & 0.72 & 0.07 & 0.12 \\
\hline Yield grade $5, \%$ & 0.8 & 2.4 & 1.6 & 1.6 & 0.98 & 0.42 & 1.00 & 0.44 \\
\hline
\end{tabular}

a,b Within a row, means without a common superscript letter are different $(P \leq 0.01)$.

${ }^{1}$ Provided $3.2 \mathrm{mg} \mathrm{Cr} / \mathrm{d}$.

${ }^{2} \mathrm{Trt}=$ effect of treatment; $\mathrm{WG}=$ effect of weight group.

was traced on tracing paper for 22 carcasses and marbling scores for these carcasses were determined by a certified USDA grader ( 1 carcass from the control heavy group, 9 carcasses from the $\mathrm{Y}+\mathrm{Cr}$ light group, and 12 carcasses from the control light group).

\section{Statistical Analyses}

Growth data (DMI, gain, and gain efficiency) were analyzed as repeated measures using the MIXED procedure of the Statistical Analysis System (version 9.2 of SAS; SAS Inst. Inc., Cary, NC) with a model that included feeding period, weight group, treatment, and any 2- or 3-way interactions as fixed effects. Block was random effect, pen was the experimental unit, and feeding period was the repeated measure with pen within treatment as the subject and compound symmetry as the covariance structure. Estimates were used to compare differences between feeding periods due to different harvest dates for light and heavy groups. Due to no significant interactions of feeding period on growth performance, feeding periods were analyzed independent of each other. Cumulative growth performance; interim measures of ADG, DMI, and G:F; plasma glucose and lactate concentrations; and noncategorical carcass traits were analyzed using the MIXED procedure with weight group, treatment, and the interaction between weight group and treatment as fixed effects; block as the random effect; and pen as the experimental unit. The GLIMMIX procedure of SAS was used to analyze incidence and severity of liver abscesses, USDA quality grades, and USDA yield grades. Weight group, treatment, and the interaction between weight group and treatment were fixed effects; block was the random effect; and pen was the experimental unit. Treatment was tested against the residual error at the 5\% level of significance. Treatment least squares means were calculated for each group. Pairwise comparisons between the least squares means of the $\mathrm{Y}+\mathrm{Cr}$ group and the least squares means of the control group were performed using the PDIFF option.

\section{RESULTS AND DISCUSSION}

Two steers were removed from the control group. One steer was removed due to an injury not related to treatment, and a urinary tract bacterial infection resulted in the death of the other steer. One steer was removed from the $\mathrm{Y}+\mathrm{Cr}$ treatment group due to an injury not related to treatment. No treatment $\times$ feeding period $\times$ weight group interactions were detected for any feedlot performance parameters ( $P \geq 0.36$; data not shown).

\section{Feedlot Performance}

The effects of $\mathrm{Y}+\mathrm{Cr}$ supplementation on interim and overall steer performance are shown in Table 2. There were no interactions between treatment and weight group or an effect of $\mathrm{Y}+\mathrm{Cr}$ on interim $\mathrm{BW}$ measurements or final BW $(P \geq 0.18)$. There was an effect of weight group $(P<0.01)$ for interim BW as per study design. Similarly, Chang et al. (1992) observed no improvement in final BW when steers were supplemented with $0.2 \mathrm{mg} / \mathrm{kg}$ (diet DM) high-Cr yeast. In addition, Swanson et al. (2000) observed no differences for BW when steers were supplemented with 100, 200, or $400 \mu \mathrm{g} / \mathrm{kg}$ (dietary DM) high-Cr yeast. Pollard et al. (2002) observed a decrease in final BW when steers were supplemented with $0.4 \mathrm{mg} \mathrm{Cr}$ yeast $/ \mathrm{kg}$ dietary 


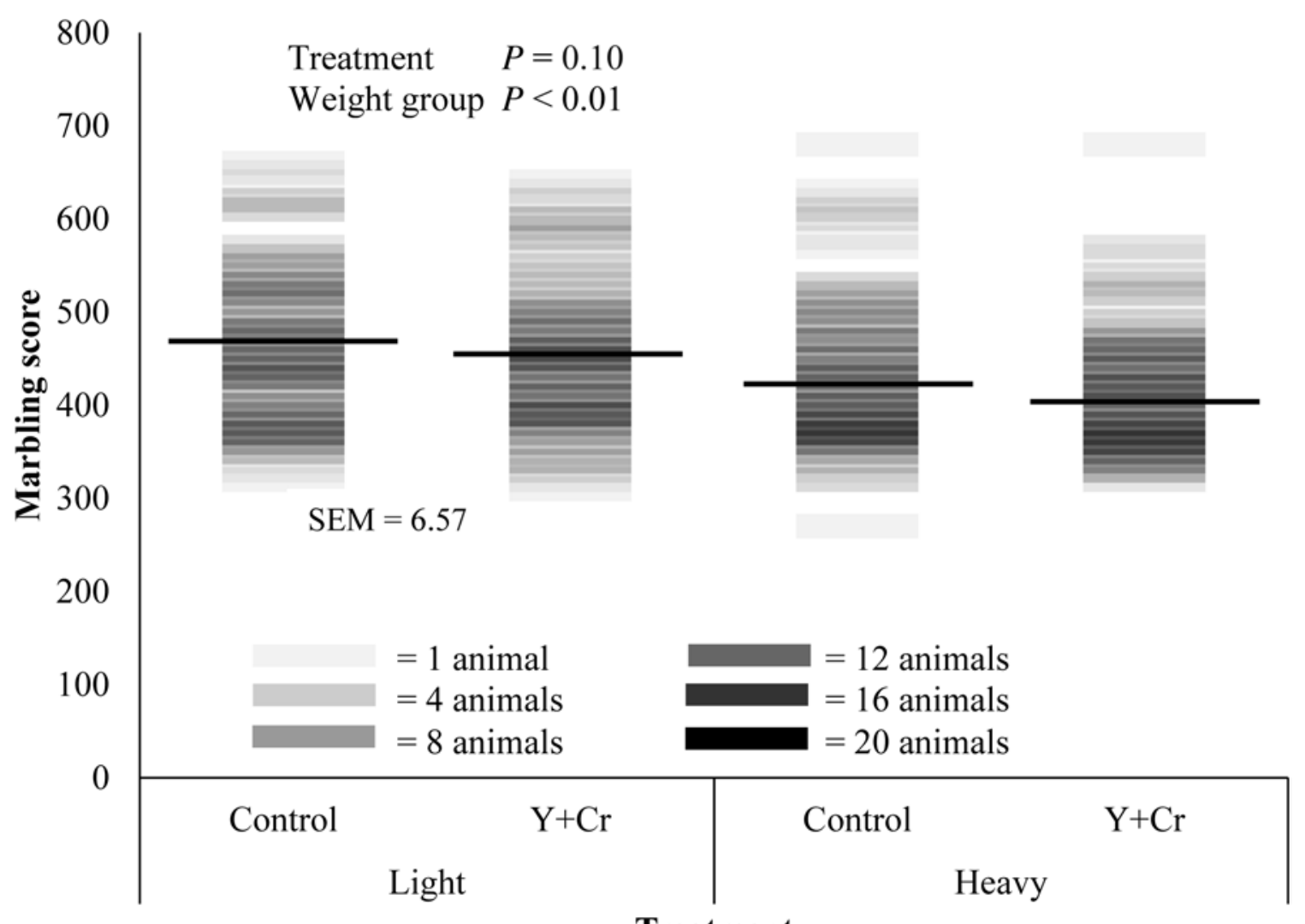

\section{Treatment}

Figure 1. Marbling scores of carcasses from steers separated into light and heavy weight blocks and supplemented 0 (control) or $3.3 \mathrm{~g} / \mathrm{d}$ of a combination of yeast and chromium propionate ( $\mathrm{Y}+\mathrm{Cr}$; Vi-COR, Mason City, IA), which provided $3.2 \mathrm{mg} \mathrm{Cr}$ per animal daily. Marbling scores were determined by camera imaging (VBG 2000; E+V Technology GmbH \& Co. KG, Oranienburg, Germany): Trace $=200$ to 299; Slight = 300 to 399; Small = 400 to 499; Modest $=500$ to 599 ; Moderate $=600$ to 699 ; Slightly abundant $=700$ to 799 . Black horizontal lines indicate treatment means. There was no interaction between treatment and weight group $(P=0.47)$.

DM compared with steers supplemented with either 0 or $0.2 \mathrm{mg} \mathrm{Cr}$ yeast/kg dietary DM, suggesting an upper tolerable limit to Cr supplementation. Danielsson and Pehrson (1998) detected no effect on final BW when bulls were fed $\mathrm{Cr}$ in the form of fodder yeast. Collectively, results of these studies suggest $\mathrm{Cr}$ supplementation has minimal impact on live BW of cattle.

No treatment $\times$ weight group interactions were detected for DMI measured for each period or for overall DMI $(P \geq 0.28)$. Supplementation with $\mathrm{Y}+\mathrm{Cr}$ tended to decrease DMI Day 22 to 42 and Day 85 to $105(P \leq$ 0.09); however, $\mathrm{Y}+\mathrm{Cr}$ supplementation did not affect overall DMI $(P=0.18)$. Dry matter intake was affected by weight group Day 1 to $21(P=0.05)$ and Day 43 to $63(P=0.03)$. In agreement, Chang et al. (1992) observed no difference in DMI when growing steers were supplemented with high-Cr yeast and Pollard et al. (2002) reported no differences in DMI of feedlot steers supplemented with a $\mathrm{Cr}$ yeast product. In addition, overall DMI was affected by weight group $(P=0.03)$. Steers in the heavy group ate, on average, more feed per day over the entire feeding when compared with light steers. These results were expected as we assumed heavier cattle would eat more to maintain a heavier BW.
An interaction between treatment and weight group was observed for ADG. Over d 1 to 21, light steers supplemented with $\mathrm{Y}+\mathrm{Cr}$ gained more than their control counterparts $(P=0.02)$, whereas no difference was observed in the heavy steers. A tendency was detected for an interaction between treatment and weight block for overall ADG $(P=0.06)$ following a pattern similar to Days 1 to 21. Steers supplemented with $\mathrm{Y}+\mathrm{Cr}$ Day 85 to 105 had decreased ADG compared with steers fed the control diet $(P=0.04)$; however, there was no effect of $\mathrm{Y}+\mathrm{Cr}$ supplementation on $\mathrm{ADG}$ at other feeding periods or for overall ADG $(P \geq 0.19)$. Average daily gain was affected by weight group Days 106 to 126 and overall ADG $(P<0.01)$, where heavy steers gained more than light steers (33 and 7\%, respectively). A treatment $\times$ weight group interaction was observed for $\mathrm{G}: \mathrm{F}(P \leq 0.05)$. Days 1 to 21 , the $\mathrm{Y}+\mathrm{Cr}$ steers from the light group were more efficient than control steers $(P=0.05)$, with no apparent differences in the heavy group. The control steers from the light group were the least efficient $(P=0.03)$ over the entire experimental feeding period. In contrast to our results, Chang et al. (1992) observed no response for ADG or G:F for growing steers supplemented with 
Table 5. Plasma glucose and lactate concentrations of steers separated into light and heavy weight group and supplemented 0 (control) or $3.3 \mathrm{~g} / \mathrm{d}$ of a combination of yeast and chromium propionate ( $\mathrm{Y}+\mathrm{Cr}$; Vi-COR, Mason City, IA) ${ }^{1}$

\begin{tabular}{|c|c|c|c|c|c|c|c|c|}
\hline \multirow[b]{2}{*}{ Item, $\mathrm{m} M$} & \multicolumn{2}{|c|}{ Light } & \multicolumn{2}{|c|}{ Heavy } & \multirow[b]{2}{*}{ SEM } & \multicolumn{3}{|c|}{$P$-value ${ }^{2}$} \\
\hline & Control & $\mathrm{Y}+\mathrm{Cr}$ & Control & $\mathrm{Y}+\mathrm{Cr}$ & & Trt & WG & $\mathrm{Trt} \times \mathrm{WG}$ \\
\hline \multicolumn{9}{|l|}{ Pretrial } \\
\hline Glucose & 3.92 & 3.90 & 3.83 & 3.90 & 0.08 & 0.78 & 0.59 & 0.58 \\
\hline Lactate & 3.27 & 2.64 & 3.52 & 2.89 & 0.32 & 0.68 & 0.44 & 0.15 \\
\hline \multicolumn{9}{|l|}{ Day 49} \\
\hline Glucose & 4.45 & 4.80 & 3.99 & 4.43 & 0.35 & 0.28 & 0.26 & 0.89 \\
\hline Lactate & 3.42 & 3.31 & 2.06 & 3.42 & 0.59 & 0.70 & 0.40 & 0.32 \\
\hline \multicolumn{9}{|l|}{ Day 94} \\
\hline Glucose & 5.08 & 4.94 & 4.32 & 4.44 & 0.23 & 0.98 & 0.02 & 0.59 \\
\hline Lactate & 4.36 & 4.16 & 3.07 & 3.24 & 0.46 & 0.97 & 0.04 & 0.70 \\
\hline
\end{tabular}

${ }^{1}$ Provided $3.2 \mathrm{mg} \mathrm{Cr}$ per animal daily.

${ }^{2} \mathrm{Trt}=$ effect of treatment; $\mathrm{WG}=$ effect of weight group.

$0.2 \mathrm{mg} / \mathrm{kg}$ (dietary DM) high-Cr yeast. Pollard et al. (2002) also observed no improvement in ADG or G:F with $0.2 \mathrm{mg} / \mathrm{kg}$ diet DM Cr yeast but observed a decrease in $\mathrm{ADG}$ and $\mathrm{G}: \mathrm{F}$ when $\mathrm{Cr}$ (as $\mathrm{Cr}$ yeast) was supplemented at $0.4 \mathrm{mg} / \mathrm{kg}$ diet DM. Average daily gain and feed efficiency of lambs were not affected by $0,0.25$, and $0.35 \mathrm{mg} / \mathrm{d}$ (equivalent to approximately 0 , 0.20 , and $0.28 \mathrm{mg} / \mathrm{kg}$ diet DM, respectively) Cr yeast supplementation (Domínguez-Vara et al., 2009). It is unclear why light cattle supplemented with $\mathrm{Y}+\mathrm{Cr}$ responded more favorably to supplementation compared with heavy steers, but it is conceivable that there were differences in $\mathrm{Cr}$ requirements for the 2 groups. Discrepancies between our results and those previously reported may reflect differences in source of $\mathrm{Cr}$, bioavailability of $\mathrm{Cr}$, Cr status of the animals, age of the animals, or amount of $\mathrm{Cr}$ in the basal diet. In addition, chromium propionate was mixed with yeast in our study, therefore making it difficult to discern if effects observed for feedlot performance were attributed to chromium propionate, yeast, or the combination.

The improvement Days 1 to 21 for ADG and feed efficiency in our study may reflect the beneficial effects of $\mathrm{Cr}$ supplementation for stressed cattle, as this was the period steers were weighed, sorted into pens, commingled with other animals, and transitioned to high-concentrate diets. Chang and Mowat (1992) observed increased ADG and G:F the first 28 $\mathrm{d}$ after arrival of stressed feeder calves supplemented with $\mathrm{Cr}$ yeast when no antibiotic was administered. Additionally, Bernhard et al. (2012b) conducted a study to assess effects of chromium propionate fed at $0,0.1,0.2$, or $0.3 \mathrm{mg} / \mathrm{kg}$ dietary $\mathrm{DM}$ during the receiving period and observed linear improvements in ADG and G:F of steers. The current results for feedlot performance suggest steers entering the feedlot with a lighter BW may benefit from yeast combined with chromium propionate.

\section{Carcass Characteristics}

No treatment $\times$ weight group interactions or effects of treatment were observed for HCW, dressing percentage, incidence of liver abscesses, LM area, or 12th rib subcutaneous fat thickness $(P \geq 0.16$; Table 3$)$. Differences between weight groups were observed for dressing percentage, incidence of liver abscesses, and LM area $(P \leq 0.05)$, wherein carcasses from heavy steers had increased dressing percentage, increased incidence of liver abscesses, and greater LM area compared with carcasses from light steers. In addition, carcasses from heavy steers tended to have heavier HCW compared with carcasses from light steers $(P=0.09)$. No interaction between treatment and weight group was observed for marbling score $(P=0.47$; Fig. 1). Supplementing steers with $\mathrm{Y}+\mathrm{Cr}$ tended to decrease marbling score $(P=$ $0.10)$ compared with carcasses from control steers; however, marbling scores from supplemented and unsupplemented steers were still within the low Choice category. Carcasses from heavy steers had decreased marbling scores compared with carcasses from light steers $(P<$ 0.01 , which may reflect differences in degree of finish, as light steers were harvested $23 \mathrm{~d}$ later than heavy steers.

Effects of $\mathrm{Y}+\mathrm{Cr}$ supplementation and weight groups on yield and quality grades are presented in Table 4. A tendency for a treatment $\times$ weight group interaction was observed for carcasses grading high choice $(P=0.07)$, where carcasses from heavy steers supplemented $\mathrm{Y}+\mathrm{Cr}$ had no carcasses that graded high Choice compared with their control counterparts and no differences were observed for light steers. No interactions between treatment and weight group were observed for remaining quality grades $(P \geq 0.43)$. Fewer carcasses from heavy steers graded mid Choice and, consequently, more carcasses from heavy steers graded Select than carcasses from light steers $(P \leq$ 0.03). Supplementing steers with $\mathrm{Y}+\mathrm{Cr}$ did not affect carcasses grading Prime, mid, or low Choice; Select; 
Standard or carcasses classified as B-maturity ( $P \geq$ $0.23)$. A treatment $\times$ weight group interaction was observed for overall yield grade $(P=0.02)$. Carcasses from light $\mathrm{Y}+\mathrm{Cr}$ steers had a decreased overall yield grade than their control counterparts, whereas no apparent difference was observed in carcasses from heavy steers $(P \leq 0.01)$. The difference in overall yield grade was reflected in percentage of carcasses that graded yield grade $1(P=0.04)$, wherein a greater percentage of carcasses from light $\mathrm{Y}+\mathrm{Cr}$-supplemented steers graded yield grade 1 compared with their control counterparts, but no difference was observed in carcasses from heavy steers. No treatment $\times$ weight group interactions were observed for carcasses grading yield grade $2,3,4$, or $5(P \geq 0.12)$. Regardless of weight group, a greater percentage of carcasses from steers supplemented with $\mathrm{Y}+\mathrm{Cr}$ graded yield grade 2 $(P=0.03)$ and, consequently, fewer carcasses from steers supplemented with $\mathrm{Y}+\mathrm{Cr}$ graded yield grade 3 $(P<0.01)$ than carcasses from control steers. In addition, a greater $(P=0.07)$ percentage of carcasses from light steers graded yield grade 4 than carcasses from heavy steers.

Reports of $\mathrm{Cr}$ supplementation and its effects on carcass traits have been inconsistent. Pollard et al. (2002) observed decreased marbling scores and yield grades in carcasses from steers supplemented with 0.4 $\mathrm{mg} \mathrm{Cr}$ yeast $/ \mathrm{kg}$ dietary DM compared with carcasses that came from steers supplemented with 0 or $0.2 \mathrm{mg}$ $\mathrm{Cr}$ yeast $/ \mathrm{kg}$ dietary DM. Carcasses from lambs supplemented with 0,400 , or $800 \mathrm{mg}$ Cr yeast $/ \mathrm{kg}$ dietary DM were observed to have decreased amounts of intramuscular fat compared with control lambs, but no other differences were observed for remaining carcass traits (Yan et al., 2008). Chromium is essential for improving insulin binding and sensitivity (Pechova and Pavlata, 2007) and may explain the decreased marbling scores and yield grade by the ability of insulin to increase lipid utilization (Dębski et al., 2004); however, not all studies demonstrated a response to Cr supplementation. Chang et al. (1992) supplemented steers with $0.2 \mathrm{mg} \mathrm{Cr}$ yeast $/ \mathrm{kg}$ dietary DM and observed no differences on carcass characteristics between carcasses from control and $\mathrm{Cr}$ yeast-supplemented animals. In addition, there was no difference in any of the carcass traits analyzed from bulls supplemented with fodder yeast compared with unsupplemented bulls (Danielsson and Pehrson, 1998). Differences observed may reflect differences in $\mathrm{Cr}$ source, $\mathrm{Cr}$ concentration, or physiological differences of the animals at the time of slaughter. Our results suggest supplementation with yeast combined with chromium propionate could decrease marbling score and yield grade, but other carcass traits were not affected.

\section{Plasma Glucose and Lactate}

Chromium plays a vital role in improving the effects of insulin binding as well as overall insulin sensitivity, therefore affecting the glucose clearance rate (Pechova and Pavlata, 2007) and possibly the concentration of glucose in plasma. Treatment effects for plasma glucose and lactate concentrations are summarized in Table 5 . No treatment $\times$ weight group interactions or effects of treatment were observed for plasma glucose concentrations on d 49 or $94(P \geq 0.28)$. An effect of weight group was detected d $94(P=0.02)$, when light steers had greater plasma glucose concentrations than heavy steers. Researchers have consistently observed no differences in either serum or plasma glucose concentrations between control cattle and cattle supplemented with chromium nicotinic acid (Kegley and Spears, 1995; Kegley et al., 1997), chromium propionate (Bernhard et al., 2012a; Spears et al., 2012), chromium tripicolinate (Bunting et al., 1994), Cr yeast (Kegley and Spears, 1995; Swanson et al., 2000), chromium chloride hexahydrate (Kegley and Spears, 1995), and chelated $\mathrm{Cr}$ (Mowat et al., 1993). In addition, plasma glucose concentrations in lambs supplemented with 0.4 or $0.8 \mathrm{mg} / \mathrm{kg}$ dietary DM Cr yeast were not different than control lambs (Yan et al., 2008). Chromium supplementation, regardless of the form administered, did not influence glucose concentrations in plasma.

Lactate is a product of glucose catabolism, is produced in cells that have high demand for glucose utilization (Kravitz, 2005), and can be converted back to glucose via the Cori cycle (Sano et al., 1997; Nelson and Cox, 2005), if necessary. No treatment $\times$ weight group interactions or effect of treatment were observed for plasma lactate concentrations on d 49 or $94(P \geq$ $0.32)$. An effect of weight group was detected d 94 ( $P=$ $0.04)$, when cattle in the light group had greater concentrations of plasma lactate than heavy steers. In agreement with our results, Sano et al. (1997) supplemented rams with $0.5 \mathrm{mg} / \mathrm{kg}$ dietary DM chelated $\mathrm{Cr}$ and observed no differences in plasma lactate concentration between supplemented or control lambs. It is conceivable the differences detected for weight group on Day 94 for plasma glucose and lactate concentrations may be reflective of the differences in degree of finish of the light and heavy cattle. Glucose and lactate, although used in a limited amount, contribute to fatty acid synthesis (Lawrence et al., 2012). The heavy steers may have been accumulating adipose tissue at a higher rate than the light steers at the d 94 blood collection, which could explain the decline in plasma glucose and lactate concentrations. Nevertheless, $\mathrm{Y}+\mathrm{Cr}$ supplementation did not affect plasma lactate concentrations.

In conclusion, yeast combined with chromium propionate improved feed efficiency and decreased yield 
grade of light weight finishing cattle but minimally affected other carcass traits and plasma glucose and lactate concentrations. Caution must be taken when interpreting results from this experiment because the product in this study consisted of yeast combined with chromium propionate, making it difficult to ascertain whether the results were due to chromium propionate, yeast, or a combination of both.

\section{LITERATURE CITED}

Bernhard, B. C., N. C. Burdick, R. J. Rathmann, J. A. Carroll, D. N. Finck, M. A. Jennings, T. R. Young, and B. J. Johnson. 2012a. Chromium supplementation alters both glucose and lipid metabolism in feedlot cattle during the receiving period. J. Anim. Sci. 90:4857-4865. doi:10.2527/jas.2011-4982

Bernhard, B. C., N. C. Burdick, W. Rounds, R. J. Rathmann, J. A. Carroll, D. N. Finck, M. A. Jennings, T. R. Young, and B. J. Johnson. 2012b. Chromium supplementation alters the performance and health of feedlot cattle during the receiving period and enhances their metabolic response to a lipopolysaccharide challenge. J. Anim. Sci. 90:3879-3888. doi:10.2527/jas.2011-4981

Bunting, L. D., J. M. Fernandez, D. L. Thompson, and L. L. Southern. 1994. Influence of chromium picolinate on glucose usage and metabolic criteria in growing Holstein calves. J. Anim. Sci. 72:1591-1599.

Chang, X., and D. N. Mowat. 1992. Supplemental chromium for stressed and growing feeder calves. J. Anim. Sci. 70:559-565.

Chang, X., D. N. Mowat, and G. A. Spiers. 1992. Carcass characteristics and tissue-mineral contents of steers fed supplemental chromium. Can. J. Anim. Sci. 72:663-669. doi:10.4141/cjas92-077

Danielsson, D.-A., and B. Pehrson. 1998. Effects of chromium supplementation on the growth and carcass quality of bulls fed a grainbased diet during the finishing period. J. Vet. Med. A Physiol. Pathol. Clin. Med. 45:219-224. doi:10.1111/j.1439-0442.1998. tb00820.x

Dębski, B., W. Zalewski, M. A. Gralak, and T. Kosla. 2004. Chromium-yeast supplementation of chicken broilers in an industrial farming system. J. Trace Elem. Med. Biol. 18:47-51. doi:10.1016/j.jtemb.2004.02.003

Domínguez-Vara, I. A., S. S. González-Muñoz, J. M. PinosRodríguez, J. L. Bórquez-Gastelum, R. Bárcena-Gama, G. Mendoza-Martínez, L. E. Zapata, and L. L. Landois-Palencia. 2009. Effects of feeding selenium-yeast and chromium-yeast to finishing lambs on growth, carcass characteristics, and blood hormones and metabolites. Anim. Feed Sci. Technol. 152:42-49. doi:10.1016/j.anifeedsci.2009.03.008

Kegley, E. B., and J. W. Spears. 1995. Immune response, glucose metabolism, and performance of stressed feeder calves fed inorganic or organic chromium. J. Anim. Sci. 73:2721-2726.
Kegley, E. B., J. W. Spears, and T. T. Brown. 1997. Effect of shipping and chromium supplementation on performance, immune response, and disease resistance of steers. J. Anim. Sci. 75:19561964.

Kravitz, L. 2005. Lactate: Not guilty as charged. IDEA Fitness J. 2:23-25.

Lawrence, T. L. J., V. R. Fowler, and J. E. Novakofski. 2012. Tissues: Basic structure and growth. In: Growth of farm animals. 3rd ed. CABI, Oxfordshire, UK. p. 57-74.

McNamara, J. P., and F. Valdez. 2005. Adipose tissue metabolism and production responses to calcium propionate and chromium propionate. J. Dairy Sci. 88:2498-2507. doi:10.3168/jds.S00220302(05)72927-1

Moonsie-Shageer, S., and D. N. Mowat. 1993. Effect of level of supplemental chromium on performance, serum constituents, and immune status of stressed feeder calves. J. Anim. Sci. 71:232-238.

Mowat, D. N. 1997. Organic chromium in animal nutrition. Chromium Books, Guelph, ON, Canada.

Mowat, D. N., X. Chang, and W. Z. Yang. 1993. Chelated chromium for stressed feeder calves. Can. J. Anim. Sci. 73:49-55. doi:10.4141/cjas93-004

Nelson, D. L., and M. M. Cox. 2005. Glycolysis, gluconeogenesis, and the pentose phosphate pathway. In: Lehninger principles of biochemistry. 4th ed. W. H. Freeman and Company, New York, NY. p. 521-559.

NRC. 2000. Nutrient requirements of beef cattle. 7th rev. ed. Natl. Acad. Press, Washington, DC.

Pechova, A., and L. Pavlata. 2007. Chromium as an essential nutrient: A review. Vet. Med. (Praha) 52:1-18.

Pollard, G. V., C. R. Richardson, and T. P. Karnezos. 2002. Effects of supplemental organic chromium on growth, feed efficiency and carcass characteristics of feedlot steers. Anim. Feed Sci. Technol. 98:121-128. doi:10.1016/S0377-8401(02)00010-X

Sano, H., D. N. Mowat, R. O. Ball, and D. R. Trout. 1997. Effect of supplemental chromium on whole-body kinetics of glucose, lactate, and propionate in rams fed a high grain diet. Comp. Biochem. Physiol. B Biochem. Mol. Biol. 118:117-121. doi:10.1016/S0305-0491(97)00023-0

Spears, J. W., C. S. Whisnant, G. B. Huntington, K. E. Lloyd, R. S. Fry, K. Krafka, A. Lamptey, and J. Hyda. 2012. Chromium propionate enhances insulin sensitivity in growing cattle. J. Dairy Sci. 95:2037-2045. doi:10.3168/jds.2011-4845

Swanson, K. C., D. L. Harmon, K. A. Jacques, B. T. Larson, C. J. Richards, D. W. Bohnert, and S. J. Paton. 2000. Efficacy of chromium-yeast supplementation for growing beef steers. Anim. Feed Sci. Technol. 86:95-105. doi:10.1016/S03778401(00)00142-5

Yan, X., W. Zhang, J. Cheng, R. Wang, D. O. Kleemann, X. Zhu, and Z. Jia. 2008. Effects of chromium yeast on performance, insulin activity, and lipid metabolism in lambs fed different dietary protein levels. Asian-Australas. J. Anim. Sci. 21:853-886. doi:10.5713/ajas.2008.70643 